nąć na jego innowacyjność, a w efekcie pozwolić na wzrost satysfakcji turystów, wyższy poziom zysku z działalności gospodarczej podmiotów, zwiększenie udziału w rynku, kreację nowego wizerunku, wzrost atrakcyjności oferty turystycznej. Mając powyższe na uwadze prognozuję dalszy dynamiczny rozwój turystyki sportowej.

\title{
Bibliografia
}

GAMMON S., ROBINSON T., 1997, Sport and Tourism: A conceptual Framework, „Journal of Sport Tourism”, Oxford, 4, (3), s. 21-26. HADZIK A., 2014, Turystyka sportowa ze szczególnym uwzględnieniem międzynarodowych widowisk sportowych, Wyd. Akademii Wychowania Fizycznego w Katowicach, Katowice.

KAZIMIERCZAK M., MALCHROWICZ-MOŚKO E., 2013, Turystyka sportowa - specyfika i trendy rozwojowe, „Folia Turistica”, 28.

Ross D., 2001, Developing Sports Tourism. An eGuide for Destination Marketers and sports Events Planners, National Laboratory for Tourism and eCommerce, University of Ilinois at Urbana Champaign, http://www.lib.teiher.gr/webnotes/sdo/Sport \%20Tourism/Sport-Tourism\%20Development\%20Guide.pdf.

STANDEVEN J., DEKNOP P., 1999, Sport Tourism, Human Kinetics, Champaign, Illinois.

http://dx.doi.org/10.18778/0867-5856.26.1.15

Agnieszka Niezgoda

Uniwersytet Ekonomiczny w Poznaniu Katedra Turystyki

\section{TURYSTYKA SPORTOWA - GŁOS W DYSKUSJI}

Termin "turystyka sportowa” można zastosować do formy turystyki wyodrębnionej na podstawie kryterium motywacji podróży. Dotyczy zatem zachowania konsumentów, którzy uwzględniają sport jako motyw wyjazdu turystycznego. Takie podejście nie różnicuje, czy turystyka sportowa ma dotyczyć wyjazdów poświęconych uprawianiu sportu czy wyjazdów w celu udziału w widowiskach sportowych (podejście takie prezentuje V.C. Middleton). Analogicznie rozpatrywana bywa turystyka kulturowa, która jest uprawiana być może zarówno przez tych, którzy biorą udział w widowiskach kulturalnych, jak też przez tych, którzy korzystają w jakikolwiek sposób z dóbr kultury.

Przyjmując kryterium motywacji należy podkreślić, że nie jest to kryterium ostre i podstawowym założeniem jest fakt, że turysta podejmuje podróż turystyczną z uwagi na więcej niż jeden motyw. Zatem uprawiając "turystykę sportową" może brać pod uwagę również wypoczynek, krajoznawstwo czy inne motywy.

Uwzględnienie różnych motywów związanych ze sportem pozwala na podział turystyki sportowej ze względu na ujęcie węższe (wyjazd w celu udziału w imprezach sportowych) oraz ujęcie szersze (wyjazd w celu uprawiania sportu). Konieczność występowania infrastruktury dla turystów uprawiających turystykę sportową oraz konieczność predyspozycji i umiejętności wymaganych do uprawiania tej formy turystyki wynika z tego, jaki jest cel wyjazdu i jakie ujęcie - szerokie czy wąskie.

Przyszłość turystyki sportowej związana jest z perspektywami dotyczącymi zachowania turystów, bo to oni i ich preferencje będą kształtować popyt turystyczny, a zgodnie z marketingowym ujęciem - również podaż turystyczną. Obserwuje się trend „zdrowego i aktywnego życia” oraz modę na aktywność fizyczną, szczególnie wśród zamożnej grupy społeczeństwa, mieszkańców miast i tzw. bogatych przedmieść. Można sądzić, że przełoży się to na wzrost zainteresowania turystyką sportową.

Anna Pawlikowska-Piechotka

Akademia Wychowania Fizycznego w Warszawie

Wydział Turystyki i Rekreacji

Politechnika Warszawska

Wydział Architektury

\section{TURYSTYKA SPORTOWA - CZYNNE I BIERNE UCZESTNICZENIE W WYDARZENIACH SPORTOWYCH (AMATORZY I ZAWODOWCY)}

Turystyka sportowa - ten termin w literaturze przedmiotu jeszcze niedawno nie pojawiał się w pracach naukowych na temat turyzmu (COOPER i in. 2005, GOŁEMBSKI, red. 2002, KUREK, red. 2007), a przecież samo zjawisko nie jest nowe. Tradycja uczestnictwa aktywnego lub pasywnego w wydarzeniach sportowych poza miejscem stałego zamieszkania ma już w warunkach europejskich prawie 3000 lat (licząc chociażby od podróży podejmowanych w celu udziału biernego lub czynnego w antycznych greckich igrzyskach olimpijskich w VIII w. p.n.e.). Zatem tu- 